\title{
La tortura: punto de vista de los derechos humanos, punto de vista del derecho internacional humanitario
}

Reina Isabel Savoff Ortega ${ }^{1}$

\section{RESUMEN}

En la búsqueda de definir la tortura en el Derecho Internacional Humanitario, he escogido la definición contenida en la Convención contra la Tortura y Otros Tratos 0 Penas Crueles, Inhumanos o Degradantes, misma que establece : "Artículo 1.1Alos efectos de la presente Convención, se entenderá por el término "tortura" todo acto por el cual se inflija intencionadamente a una persona, dolores o sufrimientos graves, ya sean físicos o mentales, con el fin de obtener de ella o de un tercero, información o una confesión, de castigarla por un acto que haya cometido, o se sospeche que ha cometido, o de intimidar o coaccionar a esa persona o a otras, o por cualquier razón basada en cualquier tipo de discriminación, cuando dichos dolores 0 sufrimientos sean infligidos por un funcionario público u otra persona en el ejercicio de funciones públicas, a instigación suya, o con su consentimiento 0 aquiescencia. No se considerarán torturas los dolores o sufrimientos que sean consecuencia únicamente de sanciones legítimas, o que sean inherentes o incidentales a éstas".

Por otro lado, el Derecho Internacional de los Derechos Humanos define los derechos humanos como los derechos que tienen todas las personas por la sola virtud de ser seres humanos, derivados de la inherente dignidad de la persona humana, y contenidos en la Declaración Universal de los Derechos Humanos y otros instrumentos legales internacionales.

El derecho internacional humanitario es un conjunto de normas que, en tiempos de guerra, protege a las personas que no participan o han dejado de participar en las hostilidades, ya sean civiles, personal militar, religioso o médico, prisioneros de guerra, restringiendo incluso los métodos de guerra (como uso de cierto equipo bélico, tácticas, etc.). Los cuatro Convenios de Ginebra $(1864,1906,1929,1949)$ y los dos Protocolos de 1977 adicionales a estos, son los principales instrumentos legales de Derecho Internacional Humanitario.

Palabras claves: Tortura, funcionarios del Estado, Derecho Internacional de Ios Derechos Humanos, Derecho Internacional Humanitario.

\footnotetext{
${ }^{1}$ Universidad Nacional Autónoma de Honduras, Maestría en Derechos Humanos y Desarrollo.
} 


\section{ABSTRACT}

In seeking to define torture in International Humanitarian Law, I have turned to the definition of torture contained in the UN Convention against Torture for guidance: "Article 1.1 For the purposes of this Convention, torture means any act by which severe pain or suffering whether physical or mental, is intentionally inflicted on a person for such purposes as obtaining from him or a third persona information or a confession, punishing him for an act he or a third person has committed or is suspected of having committed, or intimidating or coercing him or a third persona, or for any reason based on discrimination of any kind, when such pain or suffering is inflicted by or at the instigation of or with the consent of acquiescence of a public official or other person acting in an official capacity. It does not include pain or suffering arising only from, inherent in or incidental to lawful sanctions."

International Human Rights Law, defines Human Rights are the rights that all people have by virtue of being human, are derived from the inherent dignity of the human person, and enshrined in the Universal Declaration of Human Rights \& other international legal instruments. International Humanitarian Law is a set of rules which seek to limit the effects of armed conflict on civilians through protection of those who are not, or are no longer, taking part in fighting: civilians, religious/medical military personnel, prisoners of war, restrictions on the means and methods of warfare, i.e., weaponry and tactics. The four International Agreements-Geneva Conventions- $(1864,1906,1929,1949)$, and the two additional Protocols (1977) are the principal legal instruments for the International Humanitarian Law.

\section{Key Words: Torture, state actors, International Human Rights, International Humanitarian Law.}




\section{PRESENTACIÓN}

Con este trabajo pretendo dar una visión comprehensiva, integradora, del mundo del Derecho Internacional de los Derechos Humanos y del Derecho Internacional Humanitario. Y para insistir en un enfoque global del trabajo, se incluye una amplia bibliografía, a fin de reforzar el propósito mayor que se pretende alcanzar, el de plantear la discusión sobre la tortura y la existencia de estas prácticas en el Siglo XXI, así como contribuir a su prohibición o completa erradicación, objetivo que de no lograrlo a plenitud, forjará el camino para futuros investigadores que podrán proveer ampliaciones a la temática.

\section{INTRODUCCIÓN}

El Derecho Internacional Humanitario y el Derecho Internacional de los Derechos Humanos (en adelante, los Derechos Humanos) son complementarios. La finalidad de ambos es proteger a la persona; pero la protegen en circunstancias y según modalidades diferentes. El Derecho Internacional Humanitario se aplica en situaciones de conflicto armado, mientras que los Derechos Humanos, o al menos algunos de ellos, protegen a la persona humana en todo tiempo, haya guerra o paz. Si el Derecho Humanitario tiene por objeto proteger a las víctimas procurando limitar los sufrimientos provocados por la guerra, los Derechos Humanos protegen a la persona humana y favorecen su completo desarrollo.

Al Derecho Internacional Humanitario compete, principalmente, el trato debido a las personas que están en poder de la parte adversaria y la conducción de las hostilidades, mientras que la principal finalidad de los Derechos Humanos es impedir la arbitrariedad, limitando el dominio del Estado sobre los individuos sin regular la conducción de las operaciones militares.

Una cuestión conceptual importante es saber si el Derecho Internacional de los Derechos Humanos, aplicable en principio en tiempo de paz, rige también en tiempo de guerra. Entendiendo que su base filosófica es que los seres humanos los poseen siempre por el hecho de serlo, los derechos humanos serían aplicables en cualquier circunstancia. Ahora bien, la mayoría de los tratados de derechos humanos permiten que los países deroguen la mayor parte de sus disposiciones en tiempo de guerra, excepto las que se refieren al comúnmente denominado "núcleo duro" de esos derechos, que son inderogables. Se trata, básicamente, del derecho a la vida, la prohibición de la tortura y otros tratos inhumanos, la prohibición de la esclavitud y las condenas sin juicio previo. 
El tema de la tortura es un ámbito donde convergen claramente el derecho de los Derechos Humanos y el Derecho Internacional Humanitario, y donde ambos cuerpos de normas se refuerzan recíprocamente. Ambos derechos son distintos, pero son complementarios (los instrumentos jurídicos de los que derivan son diferentes y sus campos de aplicación también).

Para efectos de este trabajo nos referiremos a la tortura como violación del Derecho Internacional Humanitario y del Derecho Internacional de los Derechos Humanos.

\section{LA TORTURA DESDE EL PUNTO DE VISTA DEL DERECHO INTERNACIONALDE LOS DERECHOS HUMANOS}

Se define la tortura como: "Castigo físico o psíquico que se realiza sobre una persona con el fin de mortificarla o para que confiese algo". Sufrimiento físico 0 moral muy intenso. Suplicio, tormento ${ }^{2}$. Desde ese punto de vista estamos en presencia de un concepto común de tortura y no como institución jurídica, pues no siempre que una persona le causa sufrimiento mental a otra, existe tortura; ésta está presente cuando dicho sufrimiento es causado por un funcionario del Estado a cualquier detenido o preso, o cuando es causado por un particular instigado por un funcionario de apartado coactivo del Estado. En los textos internacionales se considera la tortura como la figura agravada de la violación del derecho a la integridad, aquella a la que se hace el mayor juicio de reproche.

Durante la Edad Media la tortura era una práctica que sin la menor autenticidad, era la forma más socorrida de indagar un supuesto delito. Pero a finales del Siglo XVIII, tras la Revolución Francesa de 1789, este bochornoso ejercicio comenzó a ser considerado como la antítesis de los derechos humanos. Sin embargo, a pesar de que en Europa era completamente ilegal, la tortura siguió siendo usada y persiste hasta nuestros días en forma alarmante, puesto que sus perpetradores, además de cumplir con la siniestra tarea de obtener una verdad, encontraron en este método diversos beneficios, tales como la rentabilidad económica de su ejercicio, amedrentar la población y su encubrimiento entre otras cosas.

En este sentido, pareciera que el principal objetivo de los torturadores es provocar un clima de terror, y que obtener información es sólo de secundaria importancia, es decir, que de lo que se trata es de enviar un claro mensaje a la sociedad. La tortura entonces, otorga a los Estados represores, dividendos muy peligrosos como

${ }^{2}$ Diccionario Manual de la Lengua Española Vox. @ 2007 Larousse. 
ocurrió en distintos países de Latinoamérica durante la denominada Guerra Sucia, cuando muchos jóvenes eran encontrados muertos con señales de tortura e incluso se llevaban a cabo represalias de esta naturaleza contra familias enteras, lo cual generalizaba el terror. El caso es que, como se ha señalado, la tortura persiste tanto como método de investigación en tiempos de paz, así como método represivo en países de conflicto.

Los diversos propósitos de esta práctica nada tienen que ver con la búsqueda de la justicia. Ya sea que se utilice como una medida coercitiva para obtener confesiones de presuntos infractores de la ley, como una forma de azoramiento dirigida a los gobernados, o con cualquier otro fin, la práctica de la tortura es inaceptable, irrazonabley detestable.

La tortura y los tratos o penas crueles, inhumanos y degradantes en el Derecho Internacional de los Derechos Humanos, están absolutamente prohibidos; sin embargo la integridad personal es hoy uno de los derechos humanos sobre el que se ejerce más presión en el mundo, así lo han denunciado recientes informes de organizaciones internacionales como Amnistía Internacional, Human Rights Watch y el Comité de Expertos de Naciones Unidas contra la Tortura.

La prohibición de la tortura y los otros tratos se ha desarrollado en múltiples instrumentos internacionales apreciándose en ellos, a la vez que importantes avances, debilidades estratégicas que hacen más complejo el control jurisdiccional internacional, partiendo de la base de que la competencia de los tribunales internacionales está sujeta a la voluntad de los Estados ${ }^{3}$.

Muchos han sido los esfuerzos por prohibir la tortura, así tenemos que:

- El primer texto jurídico internacional para prohibir específicamente la tortura, fue la Declaración Universal de Derechos Humanos (artículo $5^{4}$ ) proclamada por la Asamblea General de Naciones Unidas ${ }^{5}$, Resolución 217 A (III), del 10 de diciembre de 1948. En realidad, la declaración no fue sino la creación de lo que la propia Carta de Naciones Unidas había enunciado bajo la expresión "Derechos

\footnotetext{
${ }^{3}$ Galdámez Zelada, Liliana. Alcance de la Prohibición de la tortura y otros tratos...Centro de Estudios Institucionales. Nov.2006.. 4,(2): 662.

${ }^{4}$ Declaración Universal de los Derechos Humanos. Art. 5. "Nadie será sometido a torturas ni a penas o tratos crueles, inhumanos o degradantes".

${ }^{5}$ Firmada en San Francisco, Estados Unidos el 26 de junio de 1945 entrada en vigor. 24 de octubre de 1945, de conformidad con el artículo 110.
} 
Humanos", en los artículos 1-3 de la mencionada Carta ${ }^{6}$, es así que en su artículo $56^{7}$ los Estados Miembros se comprometieron a trabajar en cooperación para conseguir el respeto a los Derechos Humanos. Finalmente no hubo concreción de cuáles eran los derechos humanos, por las diferencias políticas y económicas de los firmantes de la Carta. El valor jurídico estaba dado en que formalmente se trata de una Resolución de la Asamblea General sin fuerza vinculante, pues constituye una mera enumeración de los derechos humanos, fuente básica de inspiración, de interpretación y de aplicación supletoria. No posee mecanismos de control ni garantía en su cumplimiento, pues nada dice expresamente dicha declaración dado a su carácter general.

- Luego de la Segunda Guerra Mundial, el 21 de octubre de 1950, entran en vigor los cuatro Convenios de Ginebra del 12 de agosto de 1949, que fueron ratificados paulatinamente: 74 Estados los ratificaron en la década de 1950, 48 en los 60, veinte en los 70 y de nuevo la misma cantidad en los 80, 26 en los 90 y 7 a partir del año 2000. En total, 194 países firmantes que hacen que hoy podamos hablar de una aplicación universal de las normas que recogen y que sirven para regular las formas de librar los conflictos, así como para limitar los efectos de los mismos. En ellas se estipula que las personas que no participan directamente en las hostilidades y las que están fuera de combate a causa de enfermedad, herida, cautiverio o por cualquier otro motivo, deben ser respetadas, protegidas contra los efectos de la guerra, y las que sufren deben ser socorridas y atendidas sin distinción. En los protocolos adicionales se extiende esa protección a toda persona afectada por un conflicto armado. Además se impone a las Partes en conflicto y a los combatientes, abstenerse de atacar a la población civil y los bienes civiles y conducir sus operaciones militares de conformidad con las normas reconocidas y de la humanidad.

${ }^{6}$ Carta de las Naciones Unidas. Art. 1-3:

1. Mantener la paz y la seguridad internacionales, $y$ con tal fin: tomar medidas colectivas eficaces para prevenir y eliminar amenazas a la paz, y para suprimir actos de agresión u otros quebrantamientos de la paz; y lograr por medios pacíficos, y de conformidad con los principios de la justicia y del derecho internacional, el ajuste 0 arreglo de controversias o situaciones internacionales susceptibles de conducir a quebrantamientos de la paz;

2. Fomentar entre las naciones relaciones de amistad basadas en el respeto al principio de la igualdad de derechos y al de la libre determinación de los pueblos, y tomar otras medidas adecuadas para fortalecer la paz universal;

3. Realizar la cooperación internacional en la solución de problemas internacionales de carácter económico, social, cultural o humanitario, y en el desarrollo y estímulo del respeto a los derechos humanos y a las libertades fundamentales de todos, sin hacer distinción por motivos de raza, sexo, idioma o religión;

${ }^{7}$ Ídem. Artículo 56. Todos los Miembros se comprometen a tomar medidas conjunta o separadamente, en cooperación con la Organización, para la realización de los propósitos consignados en el Artículo 55. 
Los Convenios y los Protocolos son aplicables en toda circunstancia, tan pronto como hay un conflicto armado (I-IV, 2; P.I, $\left.1^{8}\right)$; pero con restricciones en caso de conflicto armado no internacional de gran intensidad, en el cual sólo se aplican ciertas normas (PII). En todos los casos se deben salvaguardar los principios de humanidad (I-IV, 3). Así, están prohibidos en cualquier tiempo y lugar: el homicidio, la tortura, los castigos corporales, las mutilaciones, los atentados contra la dignidad personal, la toma de rehenes, los castigos colectivos, las ejecuciones efectuadas sin juicio previo (I-IV,3; I,II,1; III,13; IV,32,34; P.I, 75; P.II, $4,6)$.

En el artículo 3, común a los cuatro Convenios de Ginebra de 1949, figura una lista de disposiciones mínimas aplicables por las Partes, incluso en conflictos armados que no sean de índole internacional, donde se proscriben «los atentados contra la vida y la integridad corporal, especialmente [...] las mutilaciones, los tratos crueles, la tortura y los suplicios». De modo similar, en el Protocolo II se prohíben «los atentados contra la vida, la salud y la integridad física o mental de las personas, en particular [...] los tratos crueles tales como la tortura y las mutilaciones o toda forma de pena corporal ${ }^{9} »$.

Según el III Convenio de Ginebra, los Estados Partes y las autoridades respectivas tienen la obligación, en todas las circunstancias, de tratar humanamente a los prisioneros de guerra de los conflictos armados internacionales, así como de respetar su persona ${ }^{10}$. En el IV Convenio de Ginebra se prohíben los actos de violencia y de tortura contra las personas civiles protegidas en tiempo de guerra ${ }^{11}$. Por último, en el artículo 75 del Protocolo I, se amplía la prohibición a todas las personas que se encuentren en una de las situaciones previstas y se especifica que está y queda absolutamente prohibida «la tortura de cualquier clase, tanto física como mental ${ }^{12} »$.

\footnotetext{
${ }^{8}$ Los números arábigos, entre paréntesis, se refieren a los artículos de los Convenios de Ginebra y de sus Protocolos adicionales. Los números romanos indican el número del Convenio o del Protocolo (indicado con la letra P).

${ }^{9}$ Art. 4, párr. 2(a) del Protocolo adicional a los Convenios de Ginebra del 12 de agosto de 1949 relativo a la protección de las víctimas de los conflictos armados sin carácter internacional (Protocolo II), del 8 de junio de 1977.

${ }^{10}$ Arts. 13 y 14 del III Convenio de Ginebra del 12 de agosto de 1949 relativo al trato debido a los prisioneros de guerra.

${ }^{11}$ Arts. 27 y 32 del IV Convenio de Ginebra del 12 de agosto de 1949 relativo a la protección debida a las personas civiles en tiempo de guerra.

${ }^{12}$ Art. 75, párr. 2(a) (ii), del Protocolo adicional a los Convenios de Ginebra del 12 de agosto de 1949 relativo a la protección de las víctimas de los conflictos armados internacionales (Protocolo I).
} 
- Posteriormente a los Convenios de Ginebra, se suscribió el primer tratado para prohibir la tortura, el Convenio Europeo para la Protección de los Derechos Humanos y de las Libertades Fundamentales, aprobado en Roma, 4.XI.1950 (artículo $3^{13}$ ), concretando su labor en una Comisión y un Tribunal; la primera conoce de las demandas de los Estados y de las personas físicas, y después, en el plazo de tres meses traslada las actuaciones al Tribunal. Esta convención dio síntomas de crear un mecanismo de control a través de las facultades que le daba la Comisión y el Tribunal y con un término de tres meses para que este último conociera de las demandas de los Estados, después de ser presentadas a la comisión, no obstante la práctica indica que no se materializaba lo regulado en la Convención por lo ineficaz de su mecanismo de control.

- Sucesivamente, el 16 de noviembre de 1966 se firmó el Pacto de Derechos Civiles y Políticos ${ }^{14}$ que en su Artículo 7 aborda la tortura: "Nadie será sometido a torturas ni a penas 0 tratos crueles, inhumanos o degradantes. En particular, nadie será sometido sin su libre consentimiento a experimentos médicos 0 científicos." "Toda persona privada de libertad será tratada humanamente y con el respeto debido a la dignidad inherente al ser humano ${ }^{15}$." El pacto creó un organismo propio, el Comité de Derechos Humanos compuesto por 18 Miembros Expertos, nacionales de los Estados Partes. El mismo señala las medidas preventivas y garantistas para un efectivo cumplimiento de las prohibiciones de la tortura, las que fueron adoptadas por el Comité en su Sesión del 27 de julio de 1982, la cual tampoco poseía mecanismos de control de esas medidas preventivas que prohibieron la tortura.

- El 22 de noviembre de 1969 entró en vigor la Comisión Internacional de Derechos Humanos cuando se produjo una undécima ratificación. Cronológicamente es el último de los convenios internacionales vigentes sobre el tema de los Derechos Humanos. Establece que los Derechos Humanos "no nacen del hecho nacional de determinado Estado, sino que tienen como fundamento los atributos de la persona humana, razón por la cual justifican una protección internacional ${ }^{16}$. Asimismo prevé: "que toda persona tiene derecho a

\footnotetext{
${ }^{13}$ Convenio Europeo para la Protección de los Derechos Humanos y de las Libertades Fundamentales. Art. 3. Prohibición de la tortura: Nadie podrá ser sometido a tortura ni a penas o tratos inhumanos o degradantes.

${ }^{14}$ Adoptado y abierto a la firma, ratificación y adhesión por la Asamblea General en su resolución 2200 A (XXI), de 16 de diciembre de 1966.

${ }^{15}$ Pacto de Derechos Civiles y Políticos. Artículo 10.1.

${ }^{16}$ Artículo 5-1 y 5-2 de la Comisión Internacional de Derechos Humanos de 22 de noviembre de 1969.
} 
que se le respete su integridad física, psíquica y moral ${ }^{17 "}$, y que nadie debe ser sometido a torturas ni a penas o tratos crueles, inhumanos o degradantes. Toda persona privada de libertad será tratada con el respeto debido a la dignidad inherente al ser humano ${ }^{18 "}$. Finalmente, "La confesión del inculpado sólo es válida si es hecha sin coacción de ninguna naturaleza ${ }^{19}$.

- La Asamblea General de Naciones Unidas en su período de Sesiones el 9 de Diciembre de 1975, aprobó la Resolución 3452 (XXX), dejando establecido que a los efectos del Derecho Internacional, tortura es: "todo acto por el cual un funcionario público u otra persona a instigación suya, inflija intencionalmente a otra persona penas o sufrimientos graves, ya sean físicos o mentales, ya sean para obtener de ellas o de un tercero información o una confesión, de castigarla por un acto que haya cometido o que se sospeche que lo haya cometido, o de intimidar a esas personas o a otras ${ }^{20 "}$.

Asimismo establece "Todo acto de tortura u otro trato o pena cruel, inhumano 0 degradante constituye una ofensa a la dignidad humana". Estado asegurará que todos los actos de tortura definidos en el artículo 1 constituyen delitos conforme a la legislación penal ${ }^{22}$. Mediante Resolución 39/46 cuyos orígenes se encuentran en la Resolución 32/62 del 8 de diciembre de 1977, se aprobó la Convención contra la Tortura y Otros Tratos o Penas Crueles, Inhumanas o Degradantes. La Asamblea General encomendó su redacción a la Comisión de Derechos Humanos. En su artículo 4.2 establece que: "todo Estado Parte castigará esos delitos con penas adecuadas en las que se tenga en cuenta su gravedad ${ }^{23 n}$. Tiene como omisión que no se refiere a las posibles penas a imponer, pero en cuanto a la responsabilidad civil, impone en su artículo 14 el derecho de las víctimas y sus causahabientes a ser reparados 0 indemnizados justa y adecuadamente las secuelas sufridas por la victima en su cuerpo y en su persona ${ }^{24}$.

\footnotetext{
${ }^{17}$ Ibíd. Art. 5.1.

${ }^{18}$ Ibíd. Art. 5.2.

${ }^{19}$ lbíd. inhumanos o degradantes. Artículo 1. A/10034 (1975). Artículo 2.

${ }^{22}$ Ibíd. Artículo 7.

${ }^{23}$ Convención contra la tortura y otros tratos o penas crueles, inhumanas o degradantes.

${ }^{24}$ Ibíd.
}

${ }^{20}$ Declaración sobre la Protección de Todas las personas contra la tortura y otros tratos o penas crueles,

${ }^{21}$ Declaración sobre la Protección de Todas las Personas contra la tortura y otros tratos o penas crueles, Inhumanos o degradantes, A.G. res. 3452 (XXX), anexo, 30 U.N. GAOR Supp. (No. 34) p. 91, ONU Doc. 
- En junio de 1981, el Consejo de Ministros de la Organización para la Unidad Africana aprobó la Carta Africana sobre Derechos Humanos y de los Pueblos, y en su artículo 4 dice: "Los seres humanos son inviolables. Todo ser humano tendrá derecho al respeto de su vida y a la integridad de su persona. Nadie puede ser privado de este derecho arbitrariamente ${ }^{25}$. En su artículo 5 dice: "Todo individuo tendrá derecho al respeto de la dignidad inherente al ser humano y al reconocimiento de su status legal. Todas las formas de explotación y degradación del hombre, especialmente la esclavitud, el comercio de esclavos, la tortura, el castigo y el trato cruel, inhumano o degradante, serán prohibidas ${ }^{26}$.

- El año 1984, la Convención contra la Tortura de las Naciones Unidas se convirtió en el primer instrumento internacional vinculante exclusivamente dedicado a la lucha contra una de las violaciones de derechos humanos más graves y frecuentes de nuestro tiempo ${ }^{27}$. Entró en vigor el 26 de junio de 1987 de conformidad con el articulo $27(1)^{28}$.

De igual manera, en el ámbito regional también se adoptaron disposiciones vinculantes y en el XV Período Ordinario de Sesiones de laAsamblea General de la OEA llevado a cabo del 5 al 9 de diciembre de 1985, y en el campo de los derechos humanos, se aprobó la Convención Interamericana para Prevenir y Sancionar la Tortura, misma que entró en vigor el 28 de febrero de 1987, conforme al Artículo 22 de la Convención, dotando a los Estados de la Región de un marco complementario de compromisos en esa materia. Esta Convención Interamericana para Prevenir y sancionar la Tortura define a ésta como Crimen Internacional ${ }^{29}$.

No obstante la existencia de esos y otros instrumentos relevantes, lamentablemente debe admitirse que la tortura y los tratos o penas prohibidos siguen existiendo y afectando a numerosas víctimas en el mundo entero. A pesar de los esfuerzos que algunos Estados han implementado en la adopción de medidas destinadas a evitar la tortura, proteger y reparar las víctimas, sancionar a los responsables y proveer información y capacitación a las autoridades competentes, aún queda un largo camino por recorrer para erradicar una práctica inadmisible.

\footnotetext{
${ }^{25}$ CartaAfricana sobre Derechos Humanos y de los Pueblos.

${ }^{26}$ CartaAfricana sobre Derechos Humanos y de los Pueblos.

${ }^{27}$ Revista Internacional de la Cruz Roja No 147, septiembre de 1998, pp. 469-481 por Walter Kälin.

${ }^{28}$ Convención contra la Tortura y Otros Tratos o Penas Crueles, Inhumanos o Degradantes. Art. 27 (1). La presente Convención entrará en vigor el trigésimo día a partir de la fecha en que haya sido depositado el vigésimo instrumento de ratificación o de adhesión en poder del Secretario General de las Naciones Unidas.

${ }^{29}$ Véase el Texto de la Convención Interamericana para Preveniry Sancionar la Tortura en págs. 161-165.
} 
Esta realidad explica que recientemente la comunidad internacional haya adoptado otro instrumento valioso, esta vez para promover la prevención de la tortura y poner en funcionamiento un mecanismo internacional preventivo de cooperación y asesoría para los Estados, como es el Protocolo Facultativo a la Convención contra la Tortura ya mencionada. Este protocolo prevé un sistema preventivo de visitas a los lugares donde se encuentran personas privadas de libertad en los Estados Partes. Entre esos mecanismos se creó el Comité contra la Tortura como órgano encargado de vigilar el cumplimiento de las obligaciones derivadas de ese instrumento por Estados Partes, es decir por los que lo han ratificado.

Es así que la Convención prevé que los Estados deben presentar periódicamente al Comité, informes donde explican cómo aplican sus disposiciones en el ámbito interno, tanto en materia normativa como operativa. Es decir, que el Comité se interesa por conocer las normas que incorporan en el ámbito domestico las obligaciones internacionales, así como la aplicación práctica de esas normas y recursos, incluyendo la actuación de las instituciones encargadas de velar por su cumplimiento o de intervenir para proteger o garantiza el derecho a la integridad y dignidad de las personas.

Adicionalmente, la Convención ha previsto un mecanismo para que el Comité examine peticiones o denuncias de personas que alegan ser víctimas de tortura o de malos tratos a fin de que dicho órgano pueda pronunciarse sobre el caso y realizar las recomendaciones que estime pertinentes. Para que el Comité pueda ejercer esa competencia cuasi-judicial, prevista en el artículo 22 de la Convención ${ }^{30}$, los Estados Partes deben declarar expresamente su aceptación. Otra disposición de la Convención prevé que el Comité puede encarar una investigación especial en relación con un país respecto del cual recibe varias denuncias, que indican que se estaría practicando de manera sistemática la tortura. Es ese marco, el comité puede incluso prever una misión in loco, es decir una visita al país en cuestión, para evaluar más adecuadamente esa situación y poder contribuir con sus recomendaciones destinadas a mejorarla.

Todos estos mecanismos previstos en la Convención contra la Tortura, buscan aportar herramientas útiles para enfrentar esta problemática y promover acciones en

\footnotetext{
${ }^{30}$ Convención Interamericana para Prevenir y Sancionar la Tortura. Art. No. 22: La presente Convención entrará en vigor el trigésimo día a partir de la fecha en que haya sido depositado el segundo instrumento de ratificación. Para cada Estado que ratifique la Convención o se adhiera a ella después de haber sido depositado el segundo instrumento de ratificación, la Convención entrará en vigor el trigésimo día a partir de la fecha en que tal Estado haya depositado su instrumento de ratificación o adhesión.
} 
los distintos Estados Partes, encaminadas a prevenir la tortura y a proteger y garantizas a nivel mundial, el derecho a la integridad inherente al ser humano.

A este punto, cabe destacar la importancia que Honduras haya ratificado los instrumentos convencionales básicos contra la Tortura tanto en el ámbito regional interamericano como el universal, entre ellos:

- Convención Contra La Tortura y Otros Tratos o Penas Crueles, Inhumanos 0 Degradantes. (1984) Ratificada mediante Decreto No. 47-96 del Congreso Nacional, el 16 de abril de 1996. Publicada en el Diario Oficial "La Gaceta" No. 28,089 el 19 de octubre de 1996.

- Protocolo Facultativo de la Convención Contra la Tortura y Otros Tratos o Penas Crueles, Inhumanos o Degradantes. Ratificado por Decreto No. 374-2006 de 20 de enero de 2006. Publicado en la Gaceta Oficial No. 30,958 de 21 de marzo de 2006.

- Convenio para Mejorar la Suerte de los Heridos y Enfermos en las Fuerzas Armadas en Campaña. (Convenio I) (Convenio de Ginebra de 12 de agosto de 1949). Ratificado mediante Decreto No. 88 de 24 de mayo de 1993. Publicado en el Diario Oficial "La Gaceta" No.27, 431 de 20 de agosto de 1994.

- Convenio para Mejorar la Suerte de los Heridos, los Enfermos y Náufragos de las Fuerzas Armadas en el mar. (Convenio II) (Convenio de Ginebra de 12 de agosto de 1949). Ratificado mediante Decreto No. 88 de 24 de mayo de 1993. Publicado en el Diario Oficial "La Gaceta" No.27, 431 de 20 de agosto de 1994.

- Convenio Relativo al Tratamiento a los Prisioneros de Guerra. (Convenio III) (Convenio de Ginebra de 12 de agosto de 1949). Ratificado mediante Decreto No.88 de 24 de mayo de 1993. Publicado en el Diario Oficial "La Gaceta" No.27, 431 de 20 de agosto de 1994.

- Convenio Relativo a la Protección de Personas Civiles en Tiempo de Guerra. (Convenio IV) (Convenio de Ginebra de 12 de agosto de 1949) Ratificado mediante Decreto No. 88 de 24 de mayo de 1993. Publicado en el Diario Oficial "La Gaceta" No.27, 431 de 20 de agosto de 1994.

- Protocolo Adicional a los Convenios De Ginebra Del 12 De Agosto De 1949, Relativo a la Protección de las Victimas de los Conflictos Armados Internacionales. (Protocolo I) (1977) Ratificado mediante Decreto No. 88 de 24 de mayo de 1993. Publicado en el Diario Oficial "La Gaceta" No.27, 431 de 20 de agosto de 1994.

- Estatuto de la Corte Penal Internacional ratificado mediante Decreto No. 236 2002 de 30 de mayo de 2002. Publicado en el Diario Oficial "La Gaceta" No. 29, 815 de 24 de junio de 2002. Deposito: 1 de julio de 2002. 
- Convención para la Prevención y Sanción del Delito de Genocidio aprobada mediante el Acuerdo No. 436 del Poder Ejecutivo, el 23 de febrero de 1951. Ratificada mediante Decreto No. 85 del Congreso Nacional el 6 de marzo de 1951. Publicada en el Diario Oficial "La Gaceta" No. 14,356 el 26 de marzo de 1951.

Del mismo modo, Honduras incluye en su Constitución los artículos No. 68 y 182 reformado, y el Nuevo Código Procesal Penal de Honduras. Febrero 2002. Decreto No. 9-99-Eexpresando:

- Artículo 94. llegalidad de las pruebas. Cuando los Fiscales tengan en su poder pruebas y sepan que fueron obtenidas por métodos ilícitos, especialmente torturas, tratos o castigos crueles, inhumanos o degradantes y otros abusos de los derechos humanos, se abstendrán de utilizarlas; procederán contra quienes hayan empleado esos métodos para obtenerlas si consideran que se ha incurrido en responsabilidad penal, y adoptarán todas las medidas necesarias para asegurar que los responsables comparezcan ante la justicia.

- Artículo 101. A toda persona imputada se le garantiza su defensa. Tendrá derecho, en consecuencia, a: Inciso 7. A no ser sometida a técnicas o métodos que alteren sus capacidades de conocimiento y comprensión del alcance de sus actos o su libre voluntad, tales como: malos tratos, amenazas, violencia corporal o psíquica, torturas, aplicación de psicofármacos, hipnosis y polígrafo o detector de mentiras.

- Artículo 282. Inciso 4) No cometer ni inducir o permitir que se cometan torturas, tormentos u otros tratos o castigos crueles, inhumanos o degradantes, tanto en el momento de la captura como durante el tiempo que dure la detención.

- Artículo 288. Quedan prohibidos, en especial, las torturas y los malos tratamientos de obra o de palabra, las amenazas, el empleo de medidas susceptibles de producir agotamiento físico o mental, así como, la utilización de engaños y la administración de psicofármacos, la hipnosis y el empleo de polígrafos 0 aparatos similares destinados a detectar posibles mentiras del declarante, la tipificación del delito de tortura, la invalidez de las pruebas obtenidas bajo tortura, y la exclusión de la jurisdicción penal militar para la investigación y sanción de estos delitos. No obstante estos avances normativos, la preocupación por la práctica de la tortura subsiste y requiere de acciones y medidas concretas para dar mayor efectividad a las normas internas e internacionales. 


\section{LA TORTURA DESDE EL PUNTO DE VISTA DEL DERECHO INTERNACIONAL HUMANITARIO}

La presencia de la prohibición de la tortura en el derecho internacional de los Derechos Humanos, no ha de menoscabar las contribuciones del Derecho Internacional Humanitario registradas a lo largo del siglo pasado para proscribir la tortura. No mencionada explícitamente la «tortura», en el artículo 4 de los Convenios de La Haya de 1899 y 1907 sobre las leyes y costumbres de la guerra terrestre, se dispone que los prisioneros de guerra deben ser tratados con humanidad, lo que claramente excluye la tortura de los tratos aceptables.

El Derecho Internacional Humanitario contemporáneo tiene sus orígenes en dos fuentes principales: El Derecho de Ginebra, una normativa destinada a proteger las víctimas de la guerra, y El Derecho de La Haya, un conjunto de disposiciones que regulan la conducción de hostilidades.

Esta distinción es hoy un tanto artificial porque los protocolos adicionales contienen normas de los dos tipos ${ }^{31}$. El Derecho de Ginebra procura principalmente proteger a la persona cuando se ha convertido en víctima, es decir, herido, naufrago, prisionero de guerra, o persona civil en poder del adversario; mientras que el Derecho de la Haya se propone proteger a los combatientes y a los no combatientes, restringiendo los métodos y los medios de combate. En cierto sentido se puede considerar que el Derecho de la Haya se aplica antes que el Derecho de Ginebray que hace hincapié ante todo, en la prevención.

En gran medida, ambos derechos se unieron a través de la aprobación el 8 de junio de 1977 de los dos Protocolos adicionales a los Convenios de Ginebra del 12 de agosto de 1949, que actualizaron y desarrollaron no sólo las normas relativas a la protección de las víctimas de la guerra, sino también las que rigen la conducción de las hostilidades.

Podemos decir además, que el Derecho Internacional Humanitario deriva de dos iniciativas, independientes una de la otra:

La primera iniciativa fue la de Henry Dunant y sus colegas en el Comité Internacional de Socorro a los Militares Heridos (futuro Comité Internacional de la

${ }^{31}$ Y.Sandoz, C. Swinarski, B. Zimmermann (eds.), Comentario de los Protocolos del 8 de junio de 1977
adicionales a los Convenios de Ginebra del 12 de agosto de 1949, Tomo I, pág. 28, 2000. 
Cruz Roja). Su objetivo era que se prestara protección a los heridos y al personal sanitario de los ejércitos en el campo de batalla, y propició la aprobación el 22 de agosto de 1864 del primer Convenio de Ginebra para el mejoramiento de la suerte de los militares heridos en los ejércitos en campaña. El Convenio original fue revisado en 1906, 1929 y 1949. Además se extendió la protección a los heridos y a los enfermos de las Fuerzas Armadas, en el mar, mediante los artículos adicionales de 1868 (no ratificados), el Convenio de La Haya para la adaptación de los principios del Convenio de Ginebra a la guerra marítima (Convenio III de La Haya, de 1899, y Convenio X de La Haya, de 1907) y el Convenio de Ginebra para aliviar la suerte que corren los heridos, los enfermos y los náufragos de las Fuerzas Armadas en el mar, del 12 de agosto de 1949 (II Convenio).

La protección se extendió también a los prisioneros de guerra mediante el Convenio relativo al trato de los prisioneros de guerra, firmado en Ginebra, el 27 de julio de 1929, y más tarde mediante el Convenio de Ginebra del 12 de agosto de 1949 relativo al trato debido a los prisioneros de guerra (III Convenio). Los horrores de la Segunda Guerra Mundial convencieron a los Estados de la necesidad de extender la protección convencional a las víctimas civiles de la guerra. Así, se aprueba el Convenio de Ginebra del 12 de agosto de 1949 relativo a la protección debida a las personas civiles en tiempo de guerra (IV Convenio). Por último, tras la experiencia de la guerra civil española, la Conferencia Diplomática de 1949 extendió la aplicación de ciertos principios humanitarios a las víctimas de los conflictos armados no internacionales, mediante el artículo 3, común a los cuatro Convenios de Ginebra de 1949.

La cuestión central del Derecho de Ginebra ha sido siempre la protección de las víctimas: militares heridos o enfermos náufragos, prisioneros de guerra o personas civiles. Aplicando por extensión los mismos principios, se fue ampliando cada vez más la categoría de victimas protegidas. Dado que esas etapas significativas del desarrollo de ese derecho tuvieron lugar en Ginebra, se acostumbra designarlo con el nombre de derecho de Ginebra.

La segunda iniciativa es la del Zar Alejandro II, quien preocupado por el hecho de que los británicos, con quienes el imperio ruso estaba entonces en un estado de guerra (por la posesión de Asia Central y el acceso al Océano Índico), habían desarrollado un tipo de balas huecas llenas de material inflamable, y luego de balas explosivas. El Emperador pensó en prohibir el empleo de tales balas por sus ejércitos; sin embargo, por temor a que sus tropas estuvieran en inferioridad de condiciones si las privaba de esa temible arma, decidió que prohibiría su uso sólo si 
los otros soberanos también se comprometían a hacerlo. Así pues el Gabinete Imperial convocó a una conferencia en la que se aprobó la Declaración de San Petersburgo del 29 de noviembre al 11 de diciembre de 1868. En esta se establecen los principios fundamentales del derecho relativo a la conducción de hostilidades y se prohíbe el uso de proyectiles.

Tanto el Derecho Internacional Humanitario como el derecho relativo a los Derechos Humanos, han contribuido de forma específica en la lucha contra la tortura. El derecho relativo a los Derechos Humanos ha contribuido significativamente a la promoción de mecanismos para hacer respetar la prohibición de la tortura, como los procedimientos de comunicaciones individuales y los métodos de encuesta. Y es también en este derecho donde se reconoce explícitamente laidea de reparación en favor de las víctimas de la tortura.

La situación actual del Derecho Internacional muestra que juntos, los instrumentos de Derecho Internacional Humanitario y de Derechos Humanos, ofrecen un conjunto exhaustivo de normas y procedimientos para la prevención, la observancia de la prohibición y la represión de todo acto de tortura, así como para la reparación de los mismos. Tradicionalmente, ambos derechos se han influido recíprocamente de forma positiva. Hoy las deficiencias de uno de los dos derechos, pueden compensarse recurriendo a instrumentos del otro. La persistencia de la tortura en muchos países, no se debe a vacíos jurídicos, sino más bien a la falta de voluntad política de los Estados para cumplir las obligaciones emanadas del Derecho Internacional Humanitario y del derecho relativo a los Derechos Humanos. Por tanto, es conveniente distinguir los tres aspectos complementarios de la aplicación eficaz de los derechos humanos: Prevención, Cumplimiento y sanción, Reparación.

Prevención: Dada la magnitud de los efectos psicológicos que provoca en la víctima, el daño infligido por la tortura es irreparable. La importancia de la prevención es pues, primordial. Por lo que atañe a los derechos humanos, en el artículo 2, párrafo 1, de la Convención contra la Tortura, se obliga a los Estados a tomar «medidas legislativas, administrativas, judiciales o de otra índole, eficaces para impedir los actos de tortura». Tales medidas no han de limitarse a la prohibición inequívoca de todo acto de tortura, sino que también deben incluir aspectos como la capacitación del personal policial y de seguridad, la elaboración de directrices precisas acerca del trato debido a las personas privadas de libertad, la instauración, a nivel nacional, de mecanismos de control y de supervisión o la introducción de sistemas efectivos para estudiar las quejas relativas a malos tratos. Como bien 
destacó el ex relator especial sobre la tortura de la Comisión de Derechos Humanos de las Naciones Unidas, Peter Kooijmans, la tortura nunca es un fenómeno aislado: no comienza en las cámaras de tortura de este mundo. Comienza mucho antes; en toda situación donde están ausentes el respeto debido a la dignidad humana de todas las personas y el derecho al reconocimiento de esa dignidad inherente. Por lo tanto, también el trato que reciben los prisioneros y otras personas detenidas debe estar sometido a garantías contra la tortura.

Como medida preventiva contra los malos tratos, en el derecho humanitario se reconoce desde hace mucho tiempo, la necesidad de disposiciones pormenorizadas acerca del trato que reciben las personas privadas de libertad.

El deber de impedir los actos de tortura es primordial, ya que a menudo las infracciones no salen a la luz. Peter Kooijmans se ha referido muy acertadamente a la tortura calificándola como la más íntima de las violaciones de derechos humanos, puesto que tiene lugar en el aislamiento, y muy a menudo la inflige un torturador al que la víctima nunca llega a conocer y que considera a ésta como un objeto sin rostro ${ }^{32}$.

Las visitas a los lugares de detención contribuyen a acabar con ese anonimato, y por lo tanto son muy útiles para impedir la tortura. Asimismo gracias a tales visitas es posible identificar situaciones propicias a que se cometan actos de tortura, y tomar las medidas necesarias para reducir el riesgo de que esto suceda.

En este sentido la Comisión Internacional de la Cruz Roja ha desarrollado una metodología de visitas a prisiones, que ha influido mucho en los instrumentos de derechos humanos para la prevención de la tortura. El derecho relativo a los derechos humanos ha contribuido significativamente a la promoción de mecanismos para hacer respetar la prohibición de la tortura, como los procedimientos de comunicaciones individuales y los métodos de encuesta.

Cumplimiento y Sanción: En el marco del derecho relativo a los derechos humanos, se han desarrollado numerosos instrumentos para hacer respetar la prohibición de la tortura. La Convención contra la Tortura de 1984 ilustra la amplia gama de posibilidades: la obligación de los Estados de presentar periódicamente «los informes relativos a las medidas que hayan adoptado para dar efectividad a los compromisos que han contraído en virtud de la presente Convención» (artículo 19),

\footnotetext{
${ }^{32}$ Kooijmans, Peter. La tortura y otros tratos o penas crueles, inhumanos o degradantes», informe del relator especial, de la ONU-27 de diciembre de 1991.
} 
les compromete a justificar la conducta respectiva y permite al Comité contra la Tortura entablar un diálogo con el Gobierno concernido y criticarlo públicamente si ello es necesario, para mejorar la situación. Tal sistema de presentación de informes está también previsto en el Pacto Internacional de Derechos Civiles y Políticos que, inter alia, ofrece la posibilidad de que se presenten observaciones relativas a actos de tortura cometidos (artículo 7 y 40 ).

De conformidad con lo previsto en la Convención contra la Tortura, el Comité puede investigar situaciones de violaciones sistemáticas y, con la venia del Estado Parte concernido, efectuar visitas en el territorio del mismo (artículo 20). La investigación de violaciones sistemáticas de la prohibición de la tortura, incluidas las visitas a los países concernidos, atañen asimismo al relator especial sobre la tortura y a otros relatores y grupos de trabajo designados por la Comisión de Derechos Humanos de las Naciones Unidas.

Además del relator especial sobre la tortura, se ocupan de los casos de tortura y malos tratos, muchos relatores específicos para cada país, el relator especial sobre ejecuciones extrajudiciales, sumarias y arbitrarias, así como los Grupos de Trabajo sobre detenciones arbitrarias y sobre desapariciones, y éstos deben informar tanto acerca de los supuestos casos de tortura como por lo que se refiere a las conclusiones a las que lleguen.

Por último, en la Convención contra la Tortura se prevé la posibilidad de presentar comunicaciones interestatales e individuales (Art. 21 y 22). Estos procedimientos sólo pueden aplicarse si el país concernido ha hecho previamente una declaración reconociendo la competencia del Comité contra la Tortura para recibir tales comunicaciones. Tales procedimientos existen también en el marco del Pacto Internacional de Derechos Civiles y Políticos, así como en algunas convenciones zonales de derechos humanos. En el caso del Convenio Europeo de Derechos Humanos, esos mecanismos son obligatorios, y las decisiones del Tribunal Europeo de Derechos Humanos son vinculantes y han de acatarse.

Los mecanismos del derecho internacional humanitario para hacer respetar las disposiciones jurídicas son relativamente débiles. En un caso de tortura, las Potencias protectoras y el Comité Internacional de la Cruz Roja, pueden intervenir ante el Estado Parte en los Convenios de Ginebra y sus Protocolos adicionales que hayan de asumir la responsabilidad; pero no hay procedimientos formales para hacer cumplir la prohibición de la tortura. En virtud del artículo 90 del Protocolo I, se instituyó la Comisión Internacional de Encuesta que entre otras cosas, está habilitada para investigar casos graves de tortura. 
El Derecho Internacional Humanitario sin embargo, sí ha desempeñado un papel vital en el desarrollo de conceptos para la sanción penal de las infracciones graves contra las obligaciones básicas adquiridas en virtud de los Convenios de Ginebra y sus Protocolos adicionales. En los cuatro Convenios de Ginebra, Art. 50, art. 51, Art. 130 y Art. 147 de los I, II, III y IV Convenios de Ginebra, respectivamente, se incluye explícitamente la tortura en la definición de las infracciones graves.

Los Estados deben «tomar todas las oportunas medidas legislativas para determinar las adecuadas sanciones penales que se han de aplicar a las personas que hayan cometido, o dado orden de cometer» tales infracciones; asimismo, tienen «la obligación de buscar a las personas acusadas de haber cometido, u ordenado cometer, una cualquiera de las infracciones graves, y deberá hacerlas comparecer ante los propios tribunales, sea cual fuere su nacionalidad», siempre que esas personas no sean extraditadas a otro Estado Parte(Art. 49, Art. 50, Art. 129 y Art. 146 de los I, II, III y IV Convenios de Ginebra, respectivamente).

Dado este inequívoco reconocimiento de la tortura como acto que compromete la responsabilidad penal individual de quien lo perpetra, no sorprende que la tortura también figura entre los actos sancionables por los Tribunales Internacionales instituidos para juzgar los crímenes cometidos en ex Yugoslavia y en Ruanda. Además, la tortura figura también como crímenes contra la paz y la seguridad de la humanidad.

En principio, el derecho internacional de los Derechos Humanos no se refiere a la responsabilidad individual. Por lo tanto en la lucha contra la tortura, es esencial que de conformidad con los artículos 4 y 5 de la Convención contra la Tortura, la legislación interna de cada Estado sancione penalmente a toda persona culpable de actos de tortura, tanto si es nacional de ese Estado como si es extranjero no extraditado. Aunque según los trabajos preparatorios, esas disposiciones están inspiradas en convenciones y convenios relativos a la lucha contra el terrorismo, su base es el concepto de responsabilidad individual por las infracciones graves contra el derecho internacional humanitario.

Reparaciones: Como ya se ha dicho, los daños causados por actos de tortura son irreparables, y las secuelas psicológicas persisten hasta mucho después de que cicatricen las heridas físicas de las víctimas. Ahora bien, en el derecho relativo a los Derechos Humanos se reconoce que si esas víctimas obtienen cierta forma de reparación y de compensación, superarán antes los daños sufridos, ya que de este modo se toma en consideración su sentido de la justicia. La disposición más explícita que encontramos en el derecho de los Derechos Humanos relativa a la 
reparación, es el artículo 14 de la Convención contra la Tortura. Según él, todo Estado Parte «velará porque en su legislación se garanticen a la víctima de un acto de tortura, la reparación y el derecho a una indemnización justay adecuada».

En principio la reparación y la indemnización también pueden ser acordadas por los organismos internacionales que reciben comunicaciones de personas. En el artículo 41 del Convenio Europeo de Derechos Humanos, se prevé que el Tribunal Europeo de Derechos Humanos deberá, mediante una decisión vinculante para los Estados, conceder «una satisfacción equitativa a la parte lesionada».

La Corte Interamericana de Derechos Humanos ha desarrollado una jurisprudencia similar (Caso Velásquez Rodríguez vs Honduras, sentencia del 29 de julio de 1988, serie C N 4 (1998), Caso Godínez Cruz Vs Honduras. Reparaciones y Costas. Sentencia del 21 de julio de 1989. Serie C No. 8.). Otros órganos instituidos en virtud de tratados, han recomendado en varias ocasiones el pago de una indemnización a las víctimas de violaciones de los derechos humanos.

En el Derecho Internacional Humanitario se trata la cuestión de la reparación en favor de los Estados (el Art. 3 del Convenio de La Haya del 18 de octubre de 1907 sobre las leyes y costumbres de la guerra terrestre). En los cuatro Convenios de Ginebra se dispone que las Partes en conflicto no pueden exonerarse de las responsabilidades en que hayan incurrido a causa de infracciones graves y, en el Artículo 91 del Protocolo I, se estipula que la Parte en conflicto estará «obligada a indemnizar» si viola las disposiciones de los Convenios o del Protocolo, pero no se prevé la indemnización de las víctimas de torturas.

A este respecto la ocupación iraquí de Kuwait es un caso interesante, ya que en su resolución 687 de 1991, el Consejo de Seguridad decidió que Irak debía pagar una indemnización mediante un Fondo de Indemnización, por los daños causados.

La Comisión de Indemnización de las Naciones Unidas decidió acordar pagos de cantidades fijas a personas que «como consecuencia de la invasión y ocupación de Kuwait por el Iraq [...] sufrieron lesiones corporales graves», incluida la tortura (según la decisión 1 del Consejo de Administración de la Comisión de Indemnización, párr. 11-13 (30 I.L.M. 1713 [1991]), las cantidades acordadas varían entre 2.500 y 10.000 dólares EEUU. Más tarde estas cantidades se aumentaron hasta 30.000 dólares EEUU por reclamante y 60.000 dólares EEUU por unidad familiar (Decisión 8 del Consejo de Administración, párr. 3 y 4, 31 I.L.M. 1036 [1992]. 


\section{REFLEXIÓN}

Aunque en algunos momentos de la Historia ha parecido censurable reflexionar sobre la permisividad del uso de la tortura por parte del Estado, como mecanismo tendiente a la obtención de bienes de orden superior, día a día la humanidad nos golpea con ejemplos que conminan a poner nuevamente el tema sobre la mesa.

Como se expuso al principio de este trabajo, teniendo clara la definición de tortura, encontramos que efectivamente hay quienes solicitan se autorice este tipo de prácticas, sobre la base siempre utilitarista, y por qué no, del bien común. No puede dejar de mencionarse que esta postura ha encontrado excelente compañía en hechos concretos que la afianzan, y que en algunos momentos, las presentan como incontrovertibles, sobre todo cuando se tiene de presente la realidad que debe afrontar cada Estado en particular (como en el caso de varios países de América del Sur que día a día viven una extensa y sufrida guerra contra el narcoterrorismo y como la viven los estadounidense en su afamada "war on terrorism").

A tal punto se ha concebido la necesidad de estas prácticas en aras de proteger la seguridad nacional y la de los ciudadanos, que en diversos Estados se han implementado técnicas que si bien para ellos no constituyen tortura, si constriñen a los sospechosos para que entreguen información relevante con el fin de proteger el bien "mayor".

Así habrá que cuestionarse ,como lo hace Alan Dershowwitz ${ }^{33}$, hasta qué punto es justificable la utilización de medios de tortura en casos en donde existe una real amenaza de un ataque terrorista a gran escala en determinado lugar. ¿Sería viable la detención preventiva de sospechosos hasta tanto no revelen la información pertinente ¿Bajo qué parámetros y cómo podrían los agentes del Estado constreñir al sospechoso para que proporcione la información requerida? ¿Cuáles serian los límites de esas acciones y quién supervisaría que se observaran? Todas estas interrogantes deben ser cuidadosamente resueltas, pues se ponen en juego importantes derechos y deberes tanto del Estado como de las personas, existiendo el riesgo de abuso de poder.

Algunos Estados alegan estado de necesidad, lo cual convierte estas prácticas en "legales" tal y como se dispusieron en el Informe Landau de 1987, mismo que concluyó que en casos en los que es necesario obtener información para salvar

${ }^{33}$ Dershowwitz, Alan.Preemption: A Knife That Cuts Both Ways (Issues of Our Time). 2006. 
vidas, el interrogador está facultado para aplicar "un grado moderado de presión física”, lo cual contradice directamente el articulo 2 (2) de la Convención contra la Tortura $^{34}$. Así, basándose en el fenómeno terrorista que debe afrontar a diario, el Estado de Israel ha autorizado la implementación de este tipo de medidas de naturaleza física, psicológica o ambiental, ejecutadas por sus agentes en contra de una persona con el objetivo de obtener revelación de información que pueda servir para proteger la seguridad nacional y de las vidas de los ciudadanos.

De la misma manera la postura tomada por los Estados Unidos también acoge la posición de Israel en cuanto a la manera de cómo se debe combatir el terrorismo y evitar futuros incidentes, afrontando de esta manera el fenómeno del terrorismo desde una perspectiva preventiva. Con los casos de Guantánamo se evidencia la fuerte tendencia hacia la aplicación de mecanismos de tortura no sólo como pena por conductas cometidas con anterioridad, sino como medidas de prevención, lo cual resulta controversial, ya que la Enmienda VIII del Bill of Rights (8th Ammendment) prohíbe el uso de castigos crueles e inusuales.

\section{CONCLUSIONES}

- Es importante recordar que las recomendaciones de los órganos internacionales, son mecanismos de cooperación internacional para apoyar a los Estados en el cumplimiento de sus obligaciones internacionales y en la protección de los derechos y libertades fundamentales de las personas sometidas a su jurisdicción.

- La sociedad civil, y en particular las organizaciones de Derechos Humanos, las organizaciones de victimas y las victimas individualmente, contribuyen frecuentemente en la sensibilización del tema y a hacer visible la existencia de una práctica que requiere de acciones urgentes y eficaces para eliminarla.

- Las Garantías Judiciales son esenciales para asegurar una protección efectiva y para evitar tratos y actos incompatibles con la dignidad humana, aun cuando en el contexto de las medidas de lucha contra el terrorismo, los gobiernos son con frecuencia renuentes a mantener las salvaguardias jurídicas, incluyendo las garantías contra los abusos de que son víctimas los seres humanos. Esta conclusión se fundamenta en la experiencia sufrida por varias poblaciones de nuestro hemisferio en décadas recientes, particularmente por desapariciones, torturas y asesinatos cometidos o tolerados por algunos gobiernos. Esa realidad

\footnotetext{
${ }^{34}$ Convención contra la Tortura y otros Tratos o Penas Crueles, Inhumanos y Degradantes. Art. 2 (2) En ningún caso podrán invocarse circunstancias excepcionales tales como estado de guerra 0 amenaza de guerra, inestabilidad política interna o cualquier otra emergencia pública como justificación de la tortura.
} 
ha demostrado una y otra vez, que el derecho a la vida y a la integridad personal es amenazado cuando las garantías judiciales son parcial 0 totalmente suspendidas.

- Como lo manifestó el Presidente de la Comisión Interamericana de Derechos Humanos en la audiencia sobre la opinión consultiva 8/87, la Comisión Interamericana de Derechos Humanos está persuadida que, así como en el pasado reciente miles de desapariciones forzadas se hubieran evitado si las garantías judiciales, entre ellas el Habeas Corpus, hubiesen sido efectivas y los jueces se hubieran empeñado en investigar la detención concurriendo personalmente a los lugares que se denunciaron como de detención, tal recurso ahora constituye el instrumento más idóneo no sólo para corregir con prontitud los abusos de la autoridad en cuanto a la privación arbitraria de la libertad, sino también un medio eficaz para prevenir la tortura y otros apremios físicos 0 sicológicos, como el destierro, castigo tal vez el peor, del que tanto se ha abusado en el subcontinente, donde millares de exiliados conforman verdaderos éxodos.

- A modo de comprender la dimensión de los valores fundamentales del ser humanos, es necesario que "...de conformidad con los principios proclamados en la Carta de las Naciones Unidas, el reconocimiento de los derechos iguales e inalienables de todos los miembros de la familia humana es la base de la libertad, la justicia y la paz en el mundo ${ }^{35}$ ".

- El Derecho Internacional presenta crecientes avances para combatir la tortura con mayor eficacia. Es necesario actualizarnos para emplearlo a nivel local en los casos que podamos asesorar o patrocinar y para una estrategia más general de prevención.

- Es clave conocer las leyes internas en sus aciertos y límites para poder ayudar a las personas victimas, 0 a sus familiares. Es también cierto que los tratados de derechos humanos en general y de tortura en particular, son parte del derecho nacional. Es necesario conocer la ley para actuar con seguridad ante las autoridades y exigir respeto al derecho esencial a la integridad personal.

- Es recomendable apreciar las consecuencias favorables a la victima que pueda quejarse o denunciar un acto de tortura, para su mayor protección y para evitar que suceda con otras personas.

\section{BIBLIOGRAFÍA}

Carta Africana sobre Derechos Humanos y de los Pueblos. (Carta de Banjul). Aprobada: 27 de julio de 1981. XVIII Asamblea de Jefes de Estado y Gobierno de

\footnotetext{
${ }^{35}$ Preámbulo de la Convención contra la Tortura y otros Tratos o Penas Crueles, Inhumanos o Degradantes.
} 
la Organización de la Unidad Africana. Nairobi, Kenya.

Carta de las Naciones Unidas. 26 de junio 1945 entrada en vigor: 24 de octubre de 1945. San Francisco, Estados Unidos.

Código Procesal Penal de la Republica de Honduras. Decreto No.9-99-E. Tegucigalpa: Casa Blanca, S. de R.L.; Febrero del 2002.

Constitución de la Republica de Honduras. 4ta. ed. Tegucigalpa: Guaymuras; 2004.

Convención contra la Tortura y Otros Tratos o Penas Crueles, Inhumanos 0 Degradantes. Art. 2 (2). Asamblea General en su resolución 39/46, de 10 de diciembre de 1984. Entrada en vigor de conformidad con el artículo 27 (1). 26 de junio de 1987.

Convenio Europeo para la Protección de los Derechos Humanos y de las Libertades Fundamentales. Protocolo $n^{\circ}$ 4. Estrasburgo, 16.1X.1963.

IV Convenio de Ginebra del 12 de agosto de 1949 Arts. 27 y 32 relativo a la protección debida a las personas civiles en tiempo de guerra.

Declaración sobre la Protección de Todas las Personas contra la Tortura y Otros Tratos o Penas Crueles, Inhumanos o Degradantes, A.G. res. 3452 (XXX), anexo, 30 U.N. GAOR Supp. (34): 91. ONU Doc. A/10034 (1975). Art. 1, Art. 2, Art. 7.

Declaración Universal de los Derechos Humanos. Art. 5. Adoptada el 10 de diciembre de 1948.

Dershowwitz, Alan. Preemption: A Knife That Cuts Both Ways (Issues of Our Time). New York: W.W. Norton \& Company Inc; 2006.

Diccionario Manual de la Lengua Española Vox. (C)2007 Larousse, S.L.

Galdámez Zelada, Liliana. Alcance de la prohibición de la tortura y los otros tratos 0 penas crueles, inhumanas o degradantes en la jurisprudencia de la Corte Interamericana de Derechos Humanos. Revista Estudios constitucionales. (Santiago, Chile). 4 (2): 661-696, Noviembre 2006.

Kooijmans, Peter. La tortura y otros tratos o penas crueles, inhumanos 0 degradantes. Informe del relator especial, de la ONU. 27 de diciembre de 1991.

Pacto de Derechos Civiles y Políticos. Asamblea General en su resolución 2200 A (XXI). Art. 10.1.16 de diciembre de 1966.

Protocolo adicional a los Convenios de Ginebra del 12 de agosto de 1949 Art. 4, párr. 2(a) relativo a la protección de las víctimas de los conflictos armados sin carácter internacional (Protocolo II). 8 de junio de 1977.

Protocolo adicional a los Convenios de Ginebra del 12 de agosto de 1949 Art. 75, párr. 2(a) (ii), relativo a la protección de las víctimas de los conflictos armados internacionales (Protocolo I).

III Convenio de Ginebra del 12 de agosto de 1949 Arts. 13 y 14 relativo al trato debido a los prisioneros de guerra.

Walter Kälin. La lucha contra la tortura. Revista Internacional de la Cruz Roja. (147): 
469-481. Septiembre, 1998.

Y. Sandoz, C. Swinarski y B. Zimmermann (editores) Comentario de los Protocolos del 8 de junio de 1977 adicionales a los Convenios de Ginebra del 12 de agosto de 1949, relativo a la protección de las víctimas de los conflictos armados sin carácter internacional (Protocolo II) y del artículo 3 de estos Convenios. Santa Fe de Bogotá, Colombia: Comité Internacional de la Cruz Roja - Plaza \& Janés Editores. S. A. 2000. Tomo I, pág. 28. 